\title{
Canine visceral leishmaniasis and Chagas disease among dogs in Araguaína, Tocantins
}

\author{
Leishmaniose visceral canina e doença de Chagas em cães de Araguaína, Tocantins \\ Arielle Nunes Morais ${ }^{1 *}$; Marlos Gonçalves Sousa ${ }^{1}$; Luciana Regina Meireles ${ }^{2}$; \\ Norival Kesper Jr. ${ }^{2}$; Eufrosina Setsu Umezawa ${ }^{2}$ \\ ${ }^{1}$ College of Veterinary Medicine and Animal Science, Federal University of Tocantins - UFT, Araguaína, TO, Brazil \\ ${ }^{2}$ Protozoology Laboratory, Tropical Medicine Institute of São Paulo, University of São Paulo - USP, São Paulo, SP, Brazil \\ Received June 20, 2012 \\ Accepted May 2, 2013
}

\begin{abstract}
The present study analyzed serum samples from 111 male and female dogs of various ages from the municipality of Araguaína in the State of Tocantins, Brazil. Serological diagnosis of canine visceral leishmaniasis (CVL) was initially performed at the Central Laboratory (Laboratório Central - LACEN) of Araguaína, resulting in 61 positive samples by an indirect immunofluorescence assay (IIFA) ( $\geq 1: 40)$ and 50 non-reactive samples. The same samples were analyzed at the São Paulo Institute of Tropical Medicine (Instituto de Medicina Tropical de São Paulo - IMTSP) by an enzymelinked-immunosorbent assay (ELISA), resulting in 57 positive samples $(51.35 \%)$ and 54 negative samples (48.64\%). The Kappa coefficient of agreement between the tests was 0.74 . The serum samples were also subjected to a diagnostic assay for Trypanosoma cruzi (Trypomastigote Excreted/Secreted Antigens -TESA-blot) that detected five suspect animals; three of those animals were positive for leishmaniasis by ELISA but negative by IIFA. These findings suggest that the canine population of Araguaína may be simultaneously infected with Leishmania chagasi and T. cruzi. The results obtained demonstrate the difficulty of using serology to detect CVL, thus emphasizing the necessity for a reference test to diagnose CVL, particularly in regions where the infection is endemic.
\end{abstract}

Keywords: Canine visceral leishmaniasis, Chagas disease, IIFA, ELISA, TESA-blot.

\section{Resumo}

Neste estudo foram analisadas amostras de soros de 111 cães machos e fêmeas, de idades variadas, provenientes do município de Araguaína, estado do Tocantins, Brasil. O diagnóstico sorológico para leishmaniose visceral canina foi realizado, inicialmente, no Laboratório Central (LACEN) de Araguaína, resultando em 61 amostras positivas na Reação de Imunofluorescência Indireta - RIFI ( $\geq 1: 40)$ e 50 amostras não reativas. As mesmas amostras foram analisadas no Instituto de Medicina Tropical de São Paulo (IMTSP) pelo Enzyme-Linked-Immunosorbent Assay (ELISA), sendo 57 amostras positivas $(51,35 \%)$ e 54 amostras negativas (48,64\%), com coeficiente de concordância entre os testes $(\mathrm{Kappa}=0,74)$. Os soros foram submetidos também a um teste de diagnóstico para Trypanosoma cruzi (Trypomastigote Excreted/Secreted Antigens -TESA-blot), o qual detectou cinco animais suspeitos, dos quais três foram positivos para leishmaniose no ELISA, mas negativos na RIFI. Estas observaçóes mostram que a população canina de Araguaína pode também estar infectada simultaneamente com Leishmania chagasi e T. cruzi. Estes resultados mostram a dificuldade da sorologia na detecção da Leishmaniose Visceral Canina (LVC), reforçando a necessidade de um teste de referência para o diagnóstico da leishmaniose visceral canina, principalmente em regiôes endêmicas para tais infecçóes.

Palavras-chave: Leishmaniose visceral canina, doença de Chagas, RIFI, ELISA, TESA-blot.

\footnotetext{
*Corresponding author: Arielle Nunes Morais

College of Veterinary Medicine and Animal Science, Federal University of

Tocantins - UFT, Rua Sucupira, Qd B22, Lt 16, Setor Araguaína Sul,

CEP 77827-120, Araguaína, TO, Brazil

e-mail: arielle_vet@yahoo.com.br
} 


\section{Introduction}

Canine visceral leishmaniasis (CVL), also known as "kala-azar," is an infection caused by protozoa that are transmitted to animals and humans through the bite of an insect vector (DIETZE; CARVALHO, 2003). The etiological agent is an intracellular parasite of the genus Leishmania and the complex Leishmania (Leishmania) donovani that is known in the Americas as L. chagasi and transmitted by the phlebotomine Lutzomyia longipalpis (LUTZ; NEIVA, 1912; SANTOS, et al., 1998). In northern and northeastern Brazil, the vector is found in the forests and is part of the primary transmission cycle for the illness. L. longipalpis can adapt to various environments, and its population density is greater inside and around human habitations, which promotes disease transmission (BARATA et al., 2005). Other species including ducks, rodents, passerines, and chickens are considered risk factors for CVL transmission in these regions (BORGES et al., 2009).

The main clinical symptoms of CVL are as follows: development of skin lesions; periocular alopecia; nasal and/or auricular ulcers; fever; weight loss; lymphadenopathy; epistaxis; onychogryphosis; splenomegaly; conjunctivitis; emaciation; signs of renal failure, such as polyuria, polydipsia, and vomiting; neuralgia; polyarthritis; polymyositis; osteolytic lesions; and proliferative periostitis (MONTEIRO et al., 2009). Clinical diagnosis of CVL is difficult due to the myriad clinical symptoms that may be exhibited by apparently healthy animals, oligosymptomatic animals, and animals at advanced disease stages (GONTIJO; MELO, 2004). Various diagnostic assays are available, but they vary in sensitivity as a function of the clinical condition, parasite density, biological material, and the diagnostic methods used for analysis (BISUGO et al., 2007). The tests most commonly used to diagnose human visceral leishmaniasis (HVL) and CVL in Brazil are the indirect immunofluorescence assay (IIFA) and the enzyme-linkedimmunosorbent assay (ELISA).

ELISA is considered a screening method for CVL diagnosis because it is rapid and can be automated for high throughput. Additionally, ELISA has $71 \%$ to $100 \%$ sensitivity and $85 \%$ to $100 \%$ specificity (ALVES; BEVILACQUA, 2004); the antigen (crude or recombinant) and protocol used can affect these rates. The use of crude or total antigen limits the specificity of ELISA and produces cross reactivity with other trypanosomatids or even phylogenetically distant organisms (PEDROSO, 2010).

IIFA is the test of choice for epidemiological surveys because it offers multiple advantages including low cost, high speed, and ease of use (ALVES; BEVILACQUA, 2004). IIFA results are expressed as titers and are considered positive starting at 1:40. The sensitivity of IIFA ranges from $68 \%$ to $100 \%$, with $74 \%$ to $100 \%$ specificity. Similar to ELISA, IIFA produces cross-reactivity with samples from hosts infected by T. cruzi because of the phylogenetic proximity between the parasites (ALVES; BEVILACQUA, 2004; GONTIJO; MELO, 2004; ASSIS,2010). Antigens derived from promastigote forms may feature antigenic epitopes that are shared with other species of the family Trypanosomatidae, especially T. cruzi (SUNDAR; RAI, 2002). Such cross-reactions can be minimized by using purified or recombinant antigens. Purified antigens have shown better sensitivity than crude antigens, but preparation of the former is much slower and may require more sophisticated purification methods. Several recombinant antigens are already available for diagnosing HVL and CVL (GONTIJO; MELO,
2004). Thus, a requirement exists for confirmatory LV tests, such as parasitology methods and PCR. Although the parasitological method is specific, it has the disadvantages of being difficult to use in epidemiological surveys and being more invasive because puncture of the bone marrow or lymph node is required. Moreover, the method is less sensitive, yielding approximately $60 \%$ sensitivity for bone marrow smears and 30\% sensitivity for lymph node smears. PCR is becoming increasingly useful for diagnosing VL because this technique more accurately detects the seronegative population and has almost completely overcome the limitations of serological techniques by providing faster speeds with greater specificity and sensitivity, even in asymptomatic patients (FEITOSA et al., 2000). The limitations on using PCR for epidemiological surveys are the cost, availability of reagents and equipment, and poor field adaptability (ALVES; BEVILACQUA, 2004). Thus, whenever using serological diagnosis for CVL, it is important to perform a differential diagnosis that includes Chagas disease (CD) while remaining attentive to the clinical signs exhibited by the animal, if present, and epidemiological aspects, including the point of origin (whether the area is endemic for leishmaniasis or CD), presence of vectors (phlebotomine for leishmaniasis and triatomine for CD), and contact between the dog and wild animals, which are major reservoirs of both Leishmania spp. and T. cruzi (LUCIANO et al., 2009).

$\mathrm{CD}$, or American trypanosomiasis, is a zoonotic disease resulting from infection by the protozoan T. cruzi, which is transmitted by a hematophagous insect of the genus Triatoma that is commonly known as the "barber bug" or "kissing bug" and inhabits cracks in clay or wooden walls (REY, 2008). CD is endemic to various Latin American countries and is transmitted through vectors, blood transfusions, consuming contaminated foods, breast-feeding, or the transplacental route (REY, 2008).

Wild and domestic animals, including dogs, are major reservoirs of CD and can promote disease transmission (COHEN; GURTLER, 2001). Diagnosis of CD also relies on the use of serological assays such as IIFA, ELISA, and the hemagglutination inhibition (HAI) assay. More complex tests such as PCR and the western blot (WB) can be used for confirmation of both the acute and chronic forms of CD (GOMES, 2004; PINTO, 2009).

A study conducted by Correa (2010) from 2008 to 2010 in the Cardiology Outpatient Clinic of Araguaína - TO found a prevalence of $9.5 \%$ for $\mathrm{CD}$ in human patients, confirming the presence of the etiological agent for $\mathrm{CD}$ in the municipality under study. Thus, canine infection by T. cruzi at the investigated location is possible. The potential for CVL false-positives should be considered because they may lead to erroneous diagnoses and improper recommendations for euthanasia of the specified dogs.

Because Araguaína - TO has been designated a priority municipality for monitoring and control of visceral leishmaniasis (VL) in Brazil, according to the average number of cases from 2008 to 2010 (BRASIL, 2010), and because there are confirmed human cases of CD demonstrating the presence of the etiological agent in the region, the purpose of the present study was to test for serological cross-reactivity between antigens for $L$. chagasi and T. cruzi, which could yield false positives for CVL in seroepidemiological surveys. An additional aim was to investigate the status of CD among the canine population in Araguaína - TO. 


\section{Materials and Methods}

\section{Serum sampling}

IgG antibodies against $L$. chagasi and against $T$. cruzi were studied in serum samples from 111 dogs from the municipality of Araguaína - Tocantins, which is endemic for CVL and CD. All of the samples were provided by the Center for Control of Zoonotic Diseases of the municipality of Araguaína - TO and initially analyzed by IIFA at the Central Laboratory (Laboratório Central - LACEN) of Araguaína - TO. The same samples were subsequently sent to the Protozoology Laboratory at the Sáo Paulo Institute for Tropical Medicine of the University of São Paulo (Universidade de São Paulo - USP), which is a reference center for CD diagnosis, and were subjected to ELISA for the detection of anti-Leishmania antibodies, followed by a TESA-blot for the detection of anti-T. cruzi antibodies.

\section{Serological tests}

\section{IIFA}

IIFA was performed at LACEN in Araguaína - TO using a commercial kit (Biomanguinhos') according to the manufacturer's instructions.

\section{ELISA}

ELISA was performed in the Protozoology Laboratory at the Sáo Paulo Institute for Tropical Medicine - USP. Promastigotes of L. chagasi, strain MHOM/BR/1972/LD, were obtained from cultures in liquid RPMI medium containing $10 \%$ fetal serum. The parasites were concentrated by centrifugation at 2,500 rpm for 10 minutes, and the suspensions obtained were immediately frozen and stored at $-80^{\circ} \mathrm{C}$. To prepare the soluble antigen, promastigotes were suspended in 10 volumes of lysis buffer (0.05 M TRIS-HCL, pH 6.0; 4 M Urea; 5 mM EDTA; 0.5 mM PMSF; 0.1 M KCL; and $0.5 \%$ SDS), heated to $65^{\circ} \mathrm{C}$ for 15 minutes, and centrifuged at $10,000 \mathrm{rpm}$. The protein concentration of the soluble antigen was measured from the supernatant by the Bradford method, and the prepared antigen was aliquoted and stored at $-80^{\circ} \mathrm{C}$. Highbinding polystyrene Costar plates (Corning, USA) were used for the ELISA. The plates were sensitized with $10 \mathrm{mg} / \mathrm{mL}$ of $L$. chagasi (50 mL/well) diluted in $0.05 \mathrm{M}$ carbonate-bicarbonate buffer ( $\mathrm{pH}$ 9.6). After blocking with 5\% skim milk (Molico, Nestlé), $50 \mathrm{~mL}$ of serum (1:200) were added to the plates. After being incubated and washed, the plates received $50 \mathrm{~mL}$ of peroxidaseconjugated dog anti-IgG (Sigma Co, EUA). The antigen-antibody complex was visualized by addition of a chromogenic substrate (5 mg ortho-phenylenediamine - OPD; $7.5 \mathrm{~mL} \mathrm{30 \%} \mathrm{hydrogen}$ peroxide $-\mathrm{H}_{2} \mathrm{O}_{2} ; 12 \mathrm{~mL} 0.05 \mathrm{M}$ citrate-citric acid buffer, $\mathrm{pH}$ 5.0) and interrupted by the addition of $25 \mathrm{~mL} 4 \mathrm{~N} \mathrm{HCL}$. The optical density was obtained on an ELISA reader (MultiskanTitertek II) at $492 \mathrm{~nm}$.

\section{TESA-blot}

TESA-blotting was performed at the São Paulo Institute for Tropical Medicine (IMTSP) - USP following a published protocol (UMEZAWA et al., 1996, 2001). The TESA protein components were separated by SDS-PAGE (TOWBIN et al., 1979) in a 7\% gel, and the proteins were transferred to a $0.45 \mathrm{~mm}$ nitrocellulose (NTC) membrane. After blocking the NTC membrane with 5\% skim milk, the membrane containing the antigen was cut into 5- mm strips that were incubated with dog sera (1:100). The complex was formed by adding peroxidase-conjugated dog anti-IgG (Sigma Co, EUA) and visualized by adding a developing solution (6 mg 4-chloronaphthol, $2 \mathrm{~mL}$ methanol, $10 \mathrm{~mL}$ PBS, and $10 \mu \mathrm{L}$ $\mathrm{H}_{2} \mathrm{O}_{2}$ ). After bands appeared, the reaction was stopped by adding distilled water and recorded by digital photo documentation. The following proteins were used as molecular weight standards (Sigma Co, USA): carbonic anhydrase $(29 \mathrm{kDa})$, egg albumin (45 kDa), bovine albumin (66 kDa), phosphorylase B (97 kDa), galactosidase $(116 \mathrm{kDa})$, and myosin $(205 \mathrm{kDa})$.

\section{Statistical analysis}

The inter-assay agreement (Kappa statistic) was calculated using the EpiInfo 6.04 program, with ELISA as the gold standard.

\section{Results}

The positive detection rate for anti-L. chagasi IgG antibodies by IIFA (LACEN-Araguaína) was 54.95\% (61/111) and 51.35\% (57/111) by ELISA (IMTSP-USP) (Figure 1). Figure 1 shows that $14.8 \%$ (9/61) of samples that were positive by IIFA-LACEN were negative by ELISA-São Paulo, and 10\% (5/50) of samples that were negative by IIFA were positive by ELISA. The inter-assay Kappa coefficient of agreement was 0.74 . Table 1 lists differences in the results obtained by both of the methods applied.

Study of the anti-T. cruzi IgG antibodies revealed that $4.5 \%$ (5/111) of the samples were positive by TESA-blot (Figure 2). Four out of the five dogs suspected of infection by T. cruzi were also positive by ELISA for diagnosis of leishmaniasis, while three of the canines were negative by IIFA (Figure 1). Only one animal was considered co-infected with Leishmania spp. The reactivity profile of these samples by TESA-blot was quantitatively lower than the reactivity of dogs known to have CD (Figure 2, row 6).

\section{Discussion}

VL is a chronic disease that is fatal in both humans and dogs. The clinical diagnosis is complex and should be performed using a

Table 1. Comparison of the results from L. chagasi IIFA performed in Araguaína and ELISA performed in São Paulo.

\begin{tabular}{lccc}
\hline \multirow{2}{*}{ IIFA-Araguaína } & \multicolumn{2}{c}{ ELISA-Sáo Paulo } & \multirow{2}{*}{ Total } \\
\cline { 2 - 3 } & Positive & Negative & \\
\hline Positive & 52 & 9 & 61 \\
Negative & 5 & 45 & 50 \\
Total & 57 & 54 & 111 \\
\hline
\end{tabular}




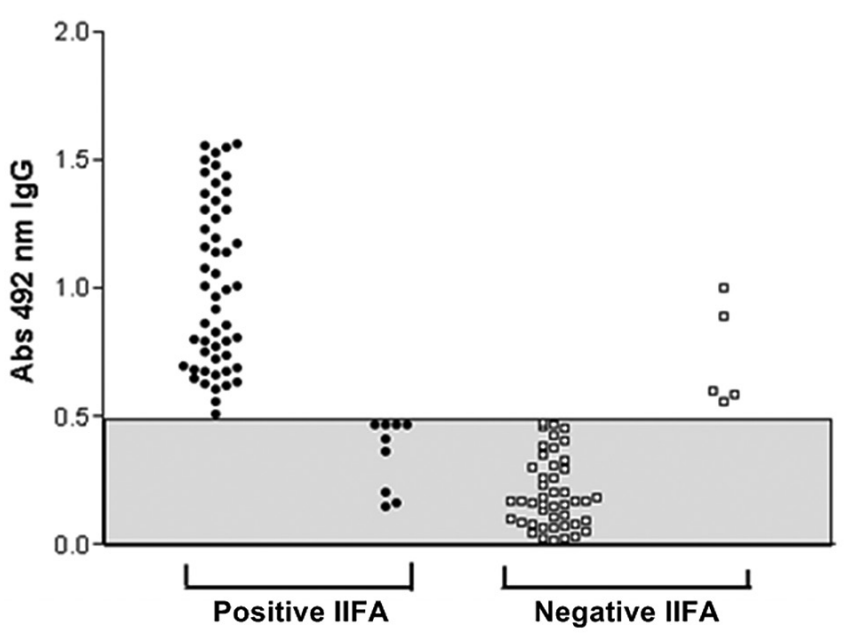

Figure 1. ELISA results for analysis of anti-L. chagasi IgG antibodies in dogs from Araguaína - TO that were positive and negative by IIFA. The shaded area represents samples considered non-reactive.

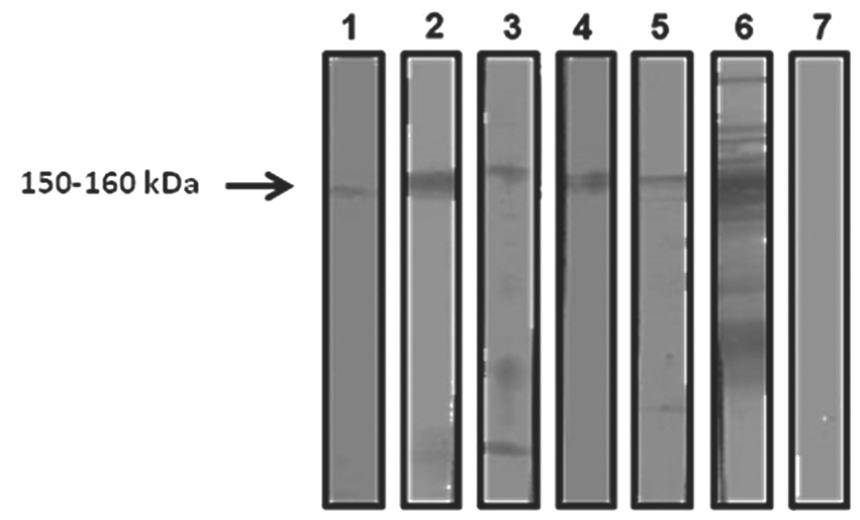

Figure 2. Reactivity profile of the TESA-blot for the detection of T. cruzi infection in dogs from Araguaína - TO. 1-5: positive samples; 6: positive control from a dog with CD; 7: negative control from a dog without CD.

combination of serological, parasitological, and/or molecular tests (SILVA, 2007). According to a study conducted by Bevilacqua et al. (2001), CVL precedes human cases because the spatial and chronological distribution of canine cases in the city of Belo Horizonte - MG has occurred much earlier than reports of human cases. Therefore, dogs are considered the main reservoir of the disease for humans. This finding highlights the importance of CVL in Araguaína due to the high regional prevalence of dogs seropositive for $L$. chagasi. Of the 5,183 canine samples analyzed in 2010, 2,544 (49.08\%) were diagnosed as positive for CVL by IIFA (LACEN/TO, 2010).

VL and CD are serious public health problems in endemic and epidemic areas where these diseases coexist due to individual and environmental risk factors such as mass migration, urbanization, and deforestation. In addition, dogs are a domestic reservoir for both diseases (BRASIL, 2006; RIBEIRO, 2010). The high rate of positivity for CVL (51.35\%) found by ELISA in the present study was much higher than the rates of $30.67 \%$ and $37.3 \%$ reported in Dourados - MS (MARCONDES, 2009) and Cuiabá - MT
(ALMEIDA et al., 2010), respectively. This finding stresses the importance of accurate disease diagnosis because cross-reactivity is possible.

TESA-blotting was used to study anti-T. cruzi antibodies. This assay consists of a WB prepared using exoantigens from trypomastigotes of T. cruzi strain Y, which is considered positive when a $150-\mathrm{kDa}$ band appears. This method has $100 \%$ sensitivity and specificity, does not suffer cross-reactivity, permits differentiation between the acute and chronic phases of CD, and is considered a confirmatory test when conventional serological results are inconclusive (UMEZAWA et al., 1996; NAKAZAWA et al., 2001; SILVA, 2007). In the present study, anti-T. cruzi antibodies were found in $4.5 \%(5 / 111)$ of the analyzed canine serum samples. Although lower than the $10.7 \%$ rate reported by Souza (2007) in Mato Grosso do Sul, the rate reported herein indicated the presence of dogs with CD in the region endemic for CVL. It should be noted that four of the samples positive for CD by TESA-blot were reactive on ELISA, and three were non-reactive by IIFA. This finding demonstrates the lack of cross-reactivity between $L$. chagasi and T. cruzi by IIFA. Similar findings were reported by Rosypal et al. (2007), who analyzed dog sera from Colombia $(n=258)$ and São Paulo ( $\mathrm{n}=107)$ and found no positivity for T. cruzi by IIFA among samples that were seropositive for $L$. chagasi. In the present study, only one dog exhibited reactivity on the applied assays and was considered co-infected by both diseases. This finding suggests the involvement of that dog in the epidemiology of CD in Araguaína.

The results obtained in the present study suggest that dogs diagnosed as seroreactive for $L$. chagasi by IIFA have CVL, even if clinical changes are not yet apparent. It is evident that the canine population in Araguaína may be simultaneously infected with L. chagasi and T. cruzi. Therefore, a broad epidemiological assessment is necessary, especially in areas where the diseases are endemic. The Kappa coefficient showed moderate agreement between IIFA and ELISA for CVL diagnosis. The samples that diverged suggest a requirement for a combination of diagnostic methods to confirm leishmaniasis in dogs.

\section{Conclusions}

The present study demonstrated the lack of cross-reactivity between L. chagasi and T. cruzi by IIFA; however, cross-reactivity was detectable when using ELISA, which uses the soluble protein antigen extract from L. chagasi promastigotes. Additionally, the recognition of anti-T. cruzi antibodies suggests involvement of the dog in the epidemiology of CD in Araguaína.

\section{References}

Almeida ABPF, Mendonça AJ, Sousa VRF. Prevalência e epidemiologia da Leishmaniose Visceral em cães e humanos, na cidade de Cuiabá, Mato Grosso, Brasil. Cienc Rural 2010; 40(7): 1610-1615. http://dx.doi. org/10.1590/S0103-84782010005000102

Alves WA, Bevilacqua PD. Reflexôes sobre a qualidade do diagnóstico da leishmaniose visceral canina em inquéritos epidemiológicos: o caso da epidemia de Belo Horizonte, Minas Gerais, Brasil, 1993-1997. Cad Saúde Pública 2004; 20(1): 259-265. PMid:15029328. http://dx.doi. org/10.1590/S0102-311X2004000100043 
Assis J, Queiroz MGP, Silveira RCV, Nunes CM, Oliveira TMFS, Noronha ACFJ, et al. Estudo comparativo dos métodos diagnósticos para Leishmaniose Visceral em cães oriundos de Ilha Solteira, SP. Rev Bras Parasitol 2010; 19(1): 17-25.

Barata RA, França-Silva JC, Mayrink W, Silva JC, Prata A, Lorosa ES, et al. Aspectos da ecologia e do comportamento de flebotomíneos em área endêmica de leishmaniose visceral, Minas Gerais. Rev Soc Bras Med Trop 2005; 38(5): 421-425. PMid:16172760. http://dx.doi.org/10.1590/ S0037-86822005000500012

Bevilacqua PD, Paixão HH, Modena CM, Castro MCPS. Urbanização da Leishmaniose Visceral em Belo Horizonte. Arq Bras Med Vet Zootec 2001; 53(1): 1-8. http://dx.doi.org/10.1590/S010209352001000100001

Bisugo MC, Araújo MFL, Taniguchi HH, Acunha E, Santos AA, Spessoto JM, et al. Avaliação do diagnóstico da Leishmaniose Visceral Canina com a utilizaçáo do teste rápido com antígeno recombinante K39 em regiôes endêmicas do Estado de São Paulo. Rev Inst Adolfo Lutz 2007; 66(2): 185-193.

Borges BKA, Silva JA, Haddad JPA, Moreira EC, Magalhães DF, Ribeiro LML, et al. Presença de animais associada ao risco de transmissão da leishmaniose visceral em humanos em Belo Horizonte, Minas Gerais. Arq Bras Med Vet Zootec 2009; 61(5): 1035-1043. http://dx.doi.org/10.1590/ S0102-09352009000500004

Brasil. Ministério da Saúde. Departamento de Vigilância Epidemiológica. Secretaria de Vigilância em Saúde. Manual de Vigilância e Controle da Leishmaniose Visceral. Brasília: Ministério da Saúde; 2006. Available from: http://portal.saude.gov.br/portal/arquivos/pdf/manual_leish_ visceral2006.pdf

Brasil. Ministério da Saúde. DATASUS - Departamento de Informática do SUS. Leishmaniose visceral - Casos confirmados Notificados no Sistema de Informação de Agravos de Notificação - Sinan Net. Brasília: Ministério da Saúde; 2010. Available from: http://dtr2004.saude.gov.br/sinanweb/ tabnet/dh?sinannet/leishvi/bases/leishvbrnet.def.

Cohen JE, Gurtler RE. Modeling household transmission of American trypanosomiasis. Science 2001; 293(5530): 694-698. PMid:11474111. http://dx.doi.org/10.1126/science.1060638

Dietze R, Carvalho SFG. Leishmaniose visceral - calazar. In: Cemerman S, Cimerman B. (Ed). Medicina tropical. São Paulo: Atheneu; 2003. p. 65-84.

Correa VR. Avaliação e epidemiologia da cardiopatia Chagásica em pacientes atendidos em Araguaina-Tocantins. [Dissertação]. São Paulo: Instituto de Pesquisas Energéticas e Nucleares; Universidade de São Paulo; 2010.

Feitosa MM, Ikeda FA, Luzivotto MCR, Perri SHV. Aspectos Clínicos de cães com Leishmaniose Visceral no município de Araçatuba - São Paulo (Brasil). Clin Vet 2000; 28: 36-44.

Gomes YM. Doença de Chagas, Diagnóstico laboratorial - situaçâo atual. Fundação Oswaldo Cruz-FIOCRUZ; 2004. [cited 2010 Dec 20]. Available from: http://www.fiocruz.br/chagas/cgi/cgilua.exe/sys/start. htm?sid= 102 .

Gontijo CMF, Melo MN. Leishmaniose visceral no Brasil: quadro atual, desafios e perspectivas. Rev Bras Epidemiol 2004; 7(3): 338-349. http:// dx.doi.org/10.1590/S1415-790X2004000300011

Laboratório Central de Saúde Pública do Tocantins - LACEN/TO. 2010.

Luciano RM, Lucheis SB, Troncarelli MZ, Luciano DM, Langoni H. Avaliação da reatividade cruzada entre antígenos de Leishmania spp e Trypanosoma cruzi na resposta sorológica de cáes pela técnica de imunofluorescência indireta (RIFI). Braz J Vet Res Anim Sci 2009; 46(3): 181-187.
Lutz A, Neiva A. Contribuição para o conhecimento das especies do gênero Phlebotomus existentes no Brasil. Mem Inst Oswaldo Cruz 1912; 4(1): 84-95. http://dx.doi.org/10.1590/S007402761912000100006

Marcondes E. Avaliação dos dados epidemiológicos de Leishmaniose Visceral canina na cidade de Dourados, estado de Mato Grosso do Sul. [online]. 2009 [cited 2010 Dec 20]. Available from: http://www.webartigos.com/ articles/29960/1/.

Monteiro MEZ, Baruque M, Neves MF. Leishmaniose Visceral em cães: Relato de caso. Revista Científica Eletrônica de Medicina Veterinária 2009; 7(12): 1-5.

Nakazawa M, Rosa DS, Pereira VRA, Moura MO, Furtado VC, Souza WV, et al. Excretory-secretory antigens of Trypanosoma cruzi are potentially useful for serodiagnosis of chronic Chagas disease. Clin Diagn Lab Immunol 2001; 8(5): 1024-1027. PMid:11527823 PMCid:96191.

Pedroso TC. Diagnóstico da Leishmaniose Visceral Canina.[online]. 2010 [cited 2010 Dec 29]. Available from: https://www.portaleducacao.com. br/veterinaria/artigos/9948/diagnostico-da-leishmaniose-visceral-canina.

Pinto P. Diagnóstico preciso para a doença de chagas. [online]. 2009 [cited 2010 Dec 13]. Available from: www.fiocruz.br.

Rey L. Parasitologia: parasitos e doenças parasitárias do homem nos trópicos ocidentais. 4. ed. Rio de Janeiro: Guanabara Koogan; 2008.

Ribeiro LML. Análise do conhecimento, sobre Leishmaniose Visceral e outras zoonoses, de docentes dos três primeiros anos do ensino fundamental em escolas da região noroeste de Belo Horizonte, Minas Gerais, 2008 [Dissertação]. Belo Horizonte: Universidade Federal de Minas Gerais; 2010.

Rosypal AC, Cortés-Vecino JA, Gennari SM, Dubey JP, Tidwell RR, Lindsay DS. Serological survey of Leishmania infantum and Trypanosoma cruzi in dogs from urban areas of Brazil and Colombia. Vet Parasitol 2007; 149: 172-177. PMid:17825991 PMCid:2238727. http://dx.doi.org/10.1016/j.vetpar.2007.08.004

Santos SO, Arias J, Ribeiro AA, Hoffmann MP, Freitas RA, Malacco MAF. Incrimination of Lutzomyia cruzi as a vector of American visceral leishmaniasis. Med Vet Entomol 1998; 12(3): 315-317. PMid:9737605. http://dx.doi.org/10.1046/j.1365-2915.1998.00104.x

Silva FS. Patologia e patogênese da leishmaniose visceral canina. Rev Trop Cienc Agr Biol 2007: 1(1): 20-31.

Souza AI. Estudo clínico da infecção natural por T. cruzi em cães residentes em um área rural de Mato Grosso do Sul-Brasil [Tese]. São Paulo: Universidade Estadual Paulista; 2007.

Sundar S, Rai M. Laboratory diagnosis of visceral leishmaniasis. Clin DiagnLab Immunol 2002; 9(5): 951-958. PMid:12204943 PMCid:120052.

Towbin H, Staehelin T, Gordon J. Electrophoretic transfer of proteins from polyacrylamide gels to nitrocellulose sheets: Procedure and some applications. Proc Natl Acad Sci USA 1979; 76(9): 43504354. PMid:388439 PMCid:411572. http://dx.doi.org/10.1073/ pnas.76.9.4350

Umezawa ES, Nascimento MS, Stolf AM. Enzyme-linked immunosorbent assay with Trypanosoma cruzi excreted-secreted antigens (TESA-ELISA) for serodiagnosis of acute and chronic Chagas's disease. Diagn Microbiol Infect Dis 2001; 39(3): 169-176. http://dx.doi.org/10.1016/S07328893(01)00216-4

Umezawa ES, Nascimento MS, Kersper N Jr, Coura JR, Borges-Pereira $\mathrm{J}$, Junqueira ACV, et al. Immunoblot assay using excreted-secreted antigens of Trypanosoma cruzi in serodiagnosis of congenital, acute, and chronic Chagas' disease. J Clin Microbiol 1996; 34(9): 2143-2147. PMid:8862574 PMCid:229206. 